\title{
The Health Crisis of Marginalized Populations during COVID-19 Pandemic: Challenges and Recommendations
}

\author{
Surobhi Chatterjee ${ }^{1}$, Shreeya Basuํ, Y. Ashutosh Bhardwaj', S.M. Yasir Arafat ${ }^{2}$, Deblina Roy ${ }^{3}$ \\ and Sujita Kumar Kar ${ }^{3^{*}}$
}

${ }^{1}$ MBBS student, King George's Medical University, Lucknow-226003, Uttar Pradesh, India

${ }^{2}$ Department of Psychiatry, Enam Medical College and Hospital, Dhaka-1340, Bangladesh

${ }^{3}$ Department of Psychiatry, King George's Medical University, Lucknow-226003, Uttar Pradesh, India

${ }^{*}$ Corresponding author: drsujita@gmail.com

Received: 10-04-2020

Revised: 20-07-2020

Accepted: 25-09-2020

\begin{abstract}
The ongoing COVID-19 pandemic is affecting the global population adversely. The impact is not limited to health only; rather extend to affect the global economy, transport, education and largely the social integrity. The impact of COVID-19 pandemic is affecting the marginalized population more intensely. The marginalized population in the community are severely affected by the COVID-19 pandemic. Community support and timely intervention for these population will prevent the spread of infection to these people as well as in the community. This review discusses the impact of COVID-19 in the marginalized population and some recommendations to deal with this issue. Extensive review of literature done by using the terms of marginalized population (transgender individuals, commercial sex workers, refugees, and migrant workforces, peoples living in prison, old age homes and hospice care) with COVID-19 in the electronic databases.
\end{abstract}

Keywords: COVID 19, Pandemic, Marginalized population

The pandemic of COVID-19 has caused a precipitous loss of life and brought in a global standstill. Strict preventive measures have caused major stagnation of livelihood, especially in those areas of mass confinement and movement restrictions. The progressively uncharted course of the pandemic has taken a toll on the wellbeing and mental health of the people. There is a need to address groups, where apart from economic deprivation, additional factors come into play in this crisis. The current pandemic affects almost every individual in almost every sphere of life. All the Governments, national agencies, public health authorities have been taking initiatives to lessen the morbidity, mortality as well as to improve the quality of life. However, there is a strong possibility to be out of the count for the people living with specialconditions such as transgender individuals, commercial sex workers, refugees, and migrant workforces, peoples living in prison, old age homes and hospice care (Fig. 1). Here, we aimed to look into the challenges of people with the special conditions so that necessary steps could be initiated to cope with the challenges.

How to cite this article: Chatterjee, S., Basu, S., Bhardwaj, Y.A., Yasir Arafat, S.M., Roy, D. and Kar, S.K. (2020). The Health Crisis of Marginalized Populations during COVID-19 Pandemic: Challenges and Recommendations. Int. J. Soc. Sci., 9(03): 185-191.

Source of Support: None; Conflict of Interest: None 


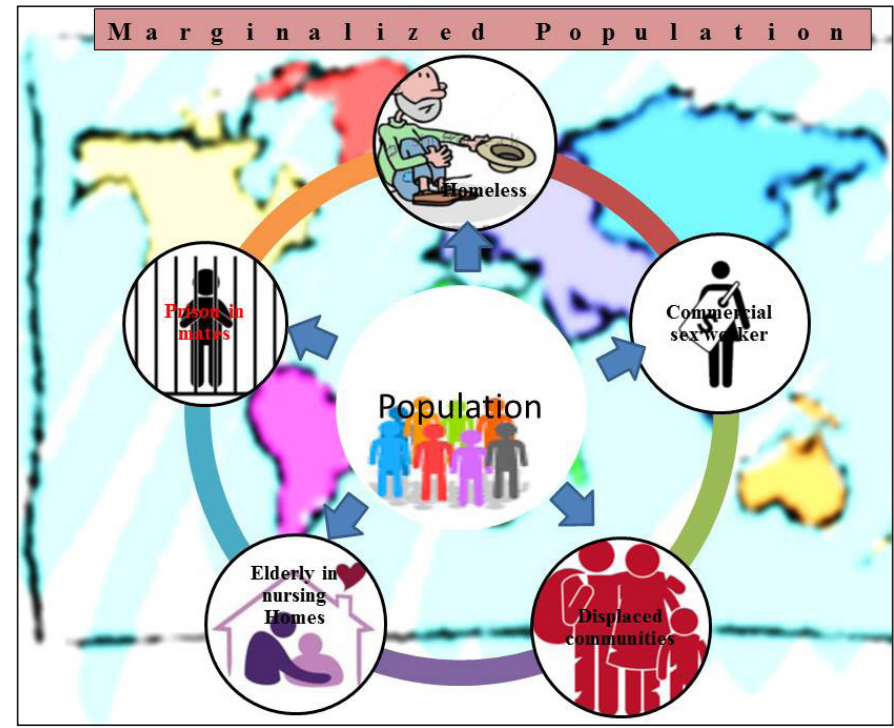

Fig. 1: Marginalized populations

\section{Homeless people}

Care of homeless individuals is a major concern as they serve both as cases and potential carriers. Their economic, social and psychological issues visibly make them the most disadvantaged sections of society. This makes them more susceptible to infectious diseases. One of the multiple challenges is their mobility which not only promotes the spread of disease but also limits contact tracing. Reports of triage discrimination against this group have also been known (Schiff et al. 2017). Barely surviving in overcrowded settings with high mortality, a public emergency or natural disaster would affect them severely. Closure of public places and clearing out of streets would mean the removal of their temporary shelters.

\section{Transgender Community}

The transgender community often lives in clusters in poor socioeconomic conditions due to low acceptance of the gender continuum in a sex binary societal construct (OCHA, 2020). Many live in parks and railway stations and seeking gratuity in ceremonies, begging in public transport or as sex workers. Trains, buses, and crowded marketplaces are their chief sources of income and also likely points of being exposed to the virus. Sadly, the shutdown of the same translates directly to a loss of daily wage for them. During a respiratory pandemic, preventive public health and sanitation measures are difficult to implement. Work and travel restrictions introduce financial set-backs as well. Crucial for the wellbeing of these otherwise ostracized people is support from within their community in the form of functions and gatherings - all of which have been brought to a stop by the pandemic (Khan et al. 2009).

The health needs of the transgender community are varied and very often poorly understood (Stroumsa, 2014). With many being unaware of their status, HIV is a major threat to their health, (Poteat et al. 2015) especially in the setting of a pandemic. Transgender individuals are more prone to develop psychiatric illnesses (Dhejne et al. 2016). Hormonal and supportive therapy they may be receiving may be halted due to restrictions implemented. Unavailability of required medication may aggravate gender dysphoria (Kennith, 2020). The transgender community is easily ignored while planning for disaster and disease and government response to the needs of this community has been inadequate in India. (Dominey-Howes et al. 2018)

\section{Commercial Sex workers (CSW)}

Commercial sex workers are less acknowledged by society and experience ostracism from policies and welfare schemes as an occupational group (Chotiner, 2020). The establishments are clustered in dense slumlike dwellings, where the public health measures regarding COVID-19 cannot be implemented. They have less access to healthcare and concerns like HIV also affect them.

In a widespread lockdown, to earn a livelihood there are chances of concealment of the disease status of both the sex workers and the clients. And in case of any suspected or COVID-19 positive CSW, tracing the clients is tedious due to societal stigma.

\section{Displaced communities}

Some of the most vulnerable to the ill-effects of the pandemic is the displaced populations of the world: refugees, asylum-seekers, migrants, stateless people and the internally displaced. The United Nations Refugee 
Agency (UNCHR) puts the total number of displaced people all over the world at 70.8 million, $84 \%$ of which reside in developing countries (Reuters, 2020; United Nations High Commissioner for, 2020).

Refugees live in some of the most densely packed areas of the world, with baffling population density running in millions per $\mathrm{km}^{2}$. There the spread of the virus becomes all too easy. Globally, their access to basic amenities, like clean water and sanitation, remain scarce. Large families crammed into tiny tents and overcrowding under larger shelters are the norm (Kluge et al. 2020). Trying circumstances, such as these prevent enforcement of public health and hygiene measures, making social distancing a mere utopian ideal (The World Bank, 2020). Healthcare facilities are insufficient, outlets ill-equipped and understaffed in these areas and pandemic preparedness lags behind substantially (Fazel et al. 2005). Traditional healthcare practices about which practitioners may be unaware also increase vulnerability (Reuters, 2020). Language is also a barrier to the dissemination of information about the disease. The internet is not accessible everywhere, not everyone has mobile phones and electricity is also not a universal privilege. Rumours and misinformation run rampant in refugee camps in times of crisis like this. Popular anti-refugee and anti-migrant notions often combined with political agenda and racial discrimination produce an environment hostile for displaced communities. Stigmatization and discrimination also result from the refugees being baselessly blamed for the spread of the diseases. Shutting down of borders, refusing asylum seekers and forceful returning refugees to their country of origin (repatriation) may result. Major depression, anxiety disorder, and post-traumatic stress disorder are prevalent in refugees (WHO, 2020).

Establishing trust is a major step to ensure that the right information reaches all and rumors are curbed, hence field workers must be locals (International Committe of Red Cross, 2020). Humanitarian organizations that try to mitigate the sufferings of the displaced people find it difficult amidst lockdowns and travel restrictions to provide services to them (Chotiner, 2020). Providing services only to refugees results in dissatisfaction among the locals outside the camps who may be in great need themselves, creating tensions between communities (Chotiner, 2020). The Inter-Agency standing committee (IASC) which is a UN forum for humanitarian coordination, has issued guidance for mental health and psychosocial support (MHPSS) in the wake of COVID-19 outbreak, in collaboration with the WHO, IFRC, IOM, and UNHCR. It especially emphasizes the needs of displaced people (OCHA, 2020).

\section{Elderly in care taking facilities}

The coronavirus pandemic has affected mankind in an unprecedented way. Most research papers have pointed out an increased case fatality rate among the 703 million elderly (United Nations et al. 2020) aged 65 years and above (Garg, 2020; Wu and McGoogan, 2020). The pandemic has brought an immense amount of mental trauma along with the fear of death in most senior citizens with the recent reports showing abandoned and dead elderly lying on their beds in old-age homes in Israel, France, and Spain (Liphshiz, 2020). In US, CDC data shows $13.8 \%$ hospitalization rate in $65+$ group and $80 \%$ deaths (CDC, 2020a). Italy has the highest average affected age reported worldwide i.e. 81 , and $23 \%$ population with more than $85 \%$ deaths over the age of 60 years (Ball and Evans, 2020). Yet it had failed to even report the death toll in nursing homes earlier which has surpassed 2700 deaths (Breuninger, 2020). CDC China also reports $80 \%$ mortality in the $60+$ age group (Liu et al. 2020)

CDC and WHO have released an updated guideline addressing the need for physical distancing rather than social distancing (CDC, 2020b). Most old age homes have cut all social contacts, which along with the limited workforce and lack of medical resources could lead to severe depression and PTSD as pointed by the 2003 SARS study on residents of Toronto (Hawryluck et al. 2004).

\section{Prisoners}

Prisons are breeding grounds for any epidemic. With over 11 million prisoners worldwide in 2018 (ICPR, 2020) and increased criminal detention in some countries for breaking lockdown laws, the world is facing a vicious circle (Akiyama et al. 2020). Outbreaks have erupted in 
Table 1: Specific issues of marginalized population and suggested recommendations

\begin{tabular}{lll}
\hline S1. No. & Community & Emergent Issues \\
\hline 1 & Homeless population & Prevention by mass containment not \\
& possible \\
$>$ & Mobility causing a high rate of infection \\
& spread and contact tracing difficult
\end{tabular}

\section{$2 \quad$ Displaced communities}

$>$ Dense accommodation with scarce resources making measures of public health and sanitation impractical limited healthcare resources with barriers to approach

> Increased susceptibility to pandemic infection due to malnutrition and deprivation

$>$ Linguistic and cultural barriers to seeking help

$>$ Hindrances in policymaking and implementation due to xenophobia and lobbyism

$3 \quad$ Elderly

The general state of low immunity

\section{Recommendations}

> Temporary arrangements and stable provision of food, water for drinking and sanitation purpose.

$>$ Crowd control during the collection of food, water, and other supplies.

$>$ Education and information dissemination regarding respiratory hygiene and personal care in local languages.

$>$ Stockpiling and mobilizing food resources, water tankers and soaps and mobile toilets to places graded in response to requirements.

$>$ Setting up of handwashing stations in water-deprived areas.

$>$ Designating areas and personnel for burial with suitable training and equipment due to pre-existing pathologies and comorbidities requiring polypharmacy.

$>$ Impaired cognition, poor self-care abilities and increased requirement of psychosocial support

$>$ Limited knowledge to grasp and utilize technological advances for information

$>$ High physical and mental comorbidities

$>$ Doorstep provision of necessities and medicines on a fixed schedule.

$>$ Telephonic conveyance of authentic information about the pandemic and supervision to ensure correct and timely medication by caretakers who cannot be present in person.

$>$ Mindful vigilance by the neighbors, to inform appropriate authorities in case of mishaps.
$>$ Positive projection in media to lift spirits.

$4 \quad$ Transgender




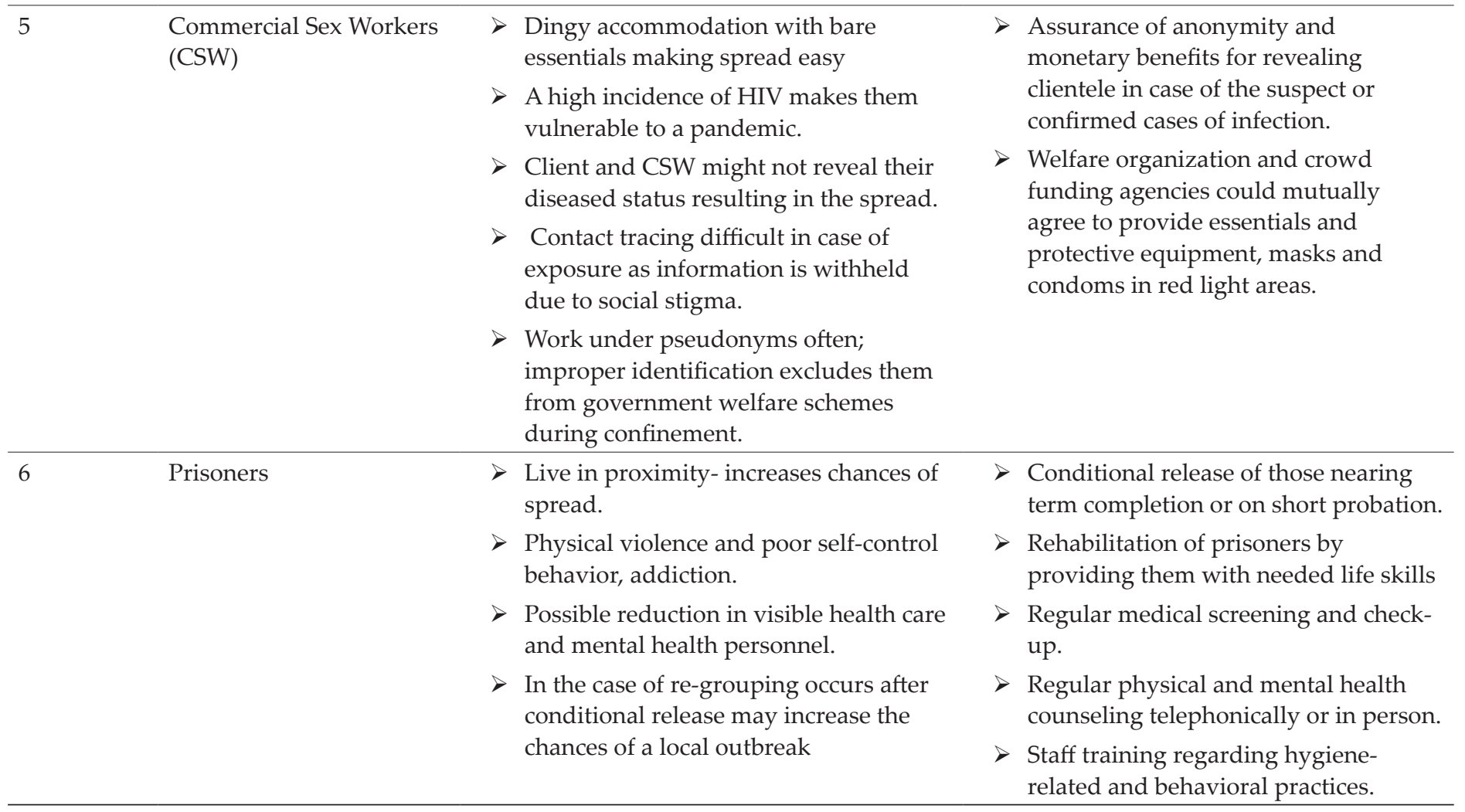

Table 2: General issues of the marginalized population and suggested recommendations

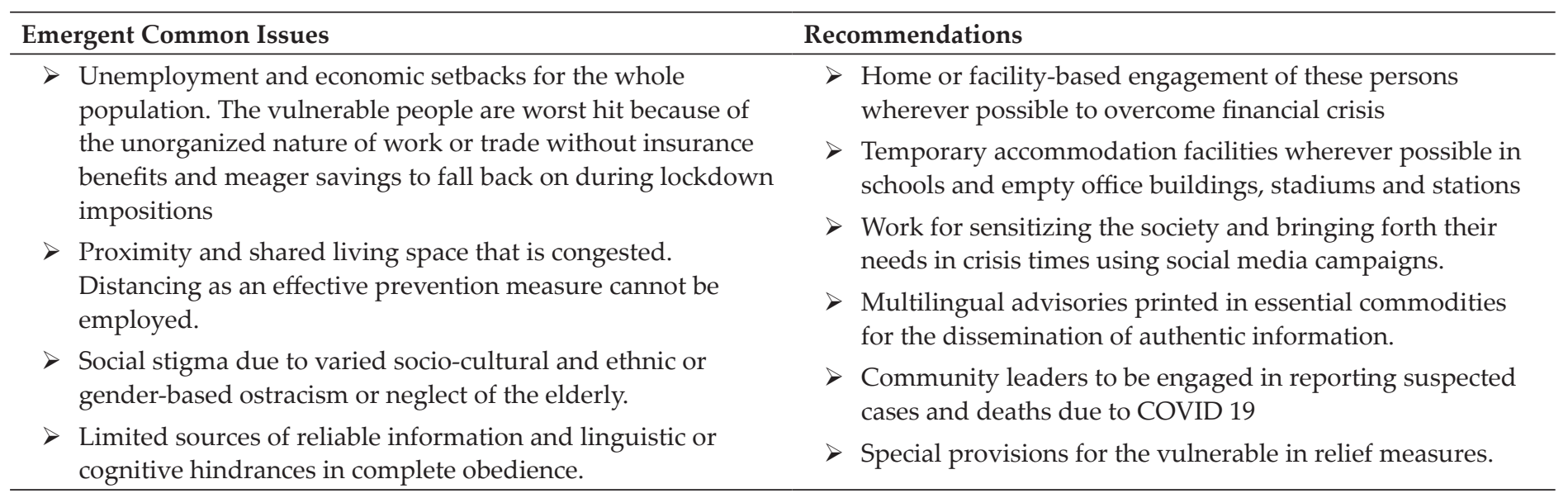

prison cells, in China and Colombia with several deaths reported in Italy, UK and Venezuela (Euronews and AFP, 2020). The USA with over 2.1 million detainees in 2016 (Williams and Ivory, 2020), had reported 1,300 confirmed cases and 32 prison deaths till $8^{\text {th }}$ April (Euronews and AFP, 2020). The role of prison response in public health is tremendous, as proved by the study on the Influenza pandemic in (Maruschak et al. 2009). Recognizing this, the $\mathrm{WHO}$ has urged for preparedness, prevention, and control of the COVID-19 outbreak in prisons. UN has also urged governments to release non-serious crime offenders (UN News, 2020). Iran had released 70,000; Afghanistan and Colombia, 10,000 prisoners (Burhan, 2020) and India have decided to release over 40,000 inmates on parole (Pandey, 2020). 
There are some general as well as some specific issues of these marginalized people. The table 1 and table 2 below summarize the specific and general issues of marginalized population.

\section{CONCLUSION}

Regardless of gender, skin color, sexual orientation, economic background, religion, disabilities, ethnicity or legal status, medical devotion should be fundamentally equal for all groups. With the governmental and authoritative measures in place, there is a need for increased sensitivity of the masses towards the less propagated but more deprived segments of the society. At the community level, crowd funding initiatives are becoming popularised. If a small residential society can cater to their nearest area of need, economic and physiological crunches could be dealt with thereby reducing mental trauma due to those issues. In areas with some considerable infection control, welfare vocations can be undertaken at the household scale. This pandemic crisis can actually stimulate the national governments, authorities and people to think about the measures to mitigate the problems faced by the marginalized community. Contribute to the building of resilience and dignity of life among them. Sensitivity among people is needed for necessary empathy that can alleviate the suffering from all of humanity.

\section{REFERENCES}

Akiyama, M.J., Spaulding, A.C. and Rich, J.D. 2020. Flattening the Curve for Incarcerated Populations - Covid-19 in Jails and Prisons. N. Engl. J. Med., 0, null. https://doi.org/10.1056/ NEJMp2005687

Ball, J.R. and Evans, C.H. 2020. Safe Passage: Astronaut Care for Exploration Missions. Committee on Creating a Vision for Space Medicine During Travel Beyond Earth Orbit, Board on Health Sciences Policy, Institute of Medicine, Washington DC.

Breuninger, S.L., Emma Newburger and Kevin. 2020. Nursing homes see surge in deaths, Italy daily coronavirus death toll falls to lowest in weeks [WWW Document]. CNBC. URL https://www.cnbc.com/2020/04/12/coronavirus-liveupdates-uk-pm-boris-johnson-discharged-from-hospital.html (accessed 4.14.20).

Burhan, F. 2020. Wider Steps Needed to Protect Prisoners' Health in Italy [WWW Document]. Hum. Rights Watch. URL https:// www.hrw.org/news/2020/03/20/wider-steps-needed-protectprisoners-health-italy (accessed 4.24.20).
CDC, 2020a. Coronavirus Disease 2019 (COVID-19) [WWW Document]. Cent. Dis. Control Prev. URL https://www. cdc.gov/coronavirus/2019-ncov/hcp/long-term-care.html (accessed 4.14.20).

CDC, 2020b. Coronavirus Disease 2019 (COVID-19) Preparedness Checklist for Nursing Homes and other Long-Term Care Settings. Center for Disease control., Geneva Switzerland.

Chotiner, I. 2020. The Danger of COVID-19 for Refugees. New Yorker.

Dhejne, C., Van Vlerken, R., Heylens, G. and Arcelus, J. 2016 Mental health and gender dysphoria: A review of the literature. Int. Rev. Psychiatry, 28: 44-57.

Dominey-Howes, D., Gorman-Murray, A. and McKinnon, S. 2018. On the disaster experiences of sexual and gender (LGBTI) minorities: insights to support inclusive disaster risk reduction policy and practice. Aust. J. Emerg. Manag., pp. 60-68.

Euronews and AFP, 2020. Death toll rises in Italian prisons as inmates riot over COVID-19 rules. Euro News.

Fazel, M., Wheeler, J. and Danesh, J. 2005. Prevalence of serious mental disorder in 7000 refugees resettled in western countries: a systematic review. The Lancet, 365: 1309-1314.

Garg, S. 2020. Hospitalization Rates and Characteristics of Patients Hospitalized with Laboratory-Confirmed Coronavirus Disease 2019 - COVID-NET, 14 States, March 1-30, 2020. MMWR Morb. Mortal. Wkly. Rep. 69. https://doi.org/10.15585/ mmwr.mm6915e3

Hawryluck, L., Gold, W.L., Robinson, S., Pogorski, S., Galea, S. and Styra, R. 2004. SARS control and psychological effects of quarantine, Toronto, Canada. Emerg. Infect. Dis., 10: 1206-1212.

ICPR, 2020. World Prison Brief I an online database comprising information on prisons and the use of imprisonment around the world [WWW Document]. ICPR.org. URL https://www. prisonstudies.org/ (accessed 4.24.20).

International Committe of Red Cross, 2020. COVID-19: Urgent action needed to counter major threat to life in conflict zones [WWW Document]. Int. Comm. Red Cross. URL https:// www.icrc.org/en/document/covid-19-urgent-action-neededcounter-major-threat-life-conflict-zones (accessed 4.24.20).

Kennith, R. 2020. COVID-19: What about the transgender community? The Hindu.

Khan, S.I., Hussain, M.I., Parveen, S., Bhuiyan, M.I., Gourab, G., Sarker, G.F., Arafat, S.M. and Sikder, J. 2009. Living on the extreme margin: social exclusion of the transgender population (hijra) in Bangladesh. J. Health Popul. Nutr., 27: 441-451.

Kluge, H.H.P., Jakab, Z., Bartovic, J., D'Anna, V. and Severoni, S. 2020. Refugee and migrant health in the COVID-19 response. The Lancet, 395: 1237-1239. 
Liphshiz, C. 2020. Coronavirus kills 15 at Amsterdam's Jewish oldage home [WWW Document]. URL https://www.timesofisrael. com/coronavirus-kills-15-at-amsterdams-jewish-old-agehome/ (accessed 4.24.20).

Liu, K., Chen, Y., Lin, R. and Han, K. 2020. Clinical features of COVID-19 in elderly patients: A comparison with young and middle-aged patients. J. Infect., 0. https://doi.org/10.1016/j. jinf.2020.03.005

Maruschak, L.M., Sabol, W.J., Potter, R.H., Reid, L.C. and Cramer, E.W. 2009. Pandemic Influenza and Jail Facilities and Populations. Am. J. Public Health, 99: S339-S344.

OCHA, 2020. COVID-19: IASC issues interim guidance for camp operations and addressing mental health and psychosocial support [WWW Document]. OCHA. URL https://www. unocha.org/story/covid-19-iasc-issues-interim-guidancecamp-operations-and-addressing-mental-health-and (accessed 4.24.20).

Pandey, T. 2020. Coronavirus: India's packed prisons raise Covid-19 alarm - Mail Today News [WWW Document]. India Today News. URL https://www.indiatoday.in/mail-today/story/indiapacked-prisons-raise-coronavirus-alarm-1661136-2020-03-30 (accessed 4.24.20).

Poteat, T., Wirtz, A.L., Radix, A., Borquez, A., Silva-Santisteban, A., Deutsch, M.B., Khan, S.I., Winter, S. and Operario, D. 2015. HIV risk and preventive interventions in transgender women sex workers. The Lancet, 385: 274-286.

Reuters, 2020. 'Just one case': fears coronavirus may spread like wildfire in world's refugee camps. Reuters.

Schiff, J.W., Pauly, B. and Schiff, R.A. 2017. Pandemic Preparedness in the Homeless Sector: Reports from Homeless People. Prehospital Disaster Med., 32: S182-S182.

Stroumsa, D. 2014. The state of transgender health care: policy, law, and medical frameworks. Am. J. Public Health, 104: e31e38.
The World Bank, 2020. COVID-19 (Coronavirus) Drives SubSaharan Africa Toward First Recession in 25 Years [WWW Document]. World Bank. URL https://www.worldbank.org/ en/news/press-release/2020/04/09/covid-19-coronavirusdrives-sub-saharan-africa-toward-first-recession-in-25-years (accessed 4.24.20).

UN News, 2020. UN rights chief urges quick action by governments to prevent devastating impact of COVID-19 in places of detention I [WWW Document]. U. N. URL https:// news.un.org/en/story/2020/03/1060252 (accessed 4.24.20).

United Nations, Department of Economic and Social Affairs, Population Division, 2020. World population ageing, 2019 highlights.

United Nations High Commissioner for, 2020. The rights and health of refugees, migrants and stateless must be protected in COVID-19 response [WWW Document]. UNHCR. URL https://www.unhcr.org/en-in/news/press/2020/3/5e836f164/ rights-health-refugees-migrants-stateless-must-protectedcovid-19-response.html (accessed 4.24.20).

WHO, 2020. Preparedness, prevention and control of coronavirus disease (COVID-19) for refugees and migrants in non-camp settings (Interim guidance). WHO 1-6. https://doi.org/ WHO/2019-nCoV/Refugees_Migrants/2020.1

Why Sub-Saharan Africa needs a unique response to COVID-19 [WWW Document], n.d. . World Econ. Forum. URL https:// www.weforum.org/agenda/2020/03/why-sub-saharan-africaneeds-a-unique-response-to-covid-19/ (accessed 4.21.20).

Williams, T. and Ivory, D. 2020. Chicago's Jail Is Top U.S. Hot Spot as Virus Spreads Behind Bars. N. Y. Times.

Wu, Z., McGoogan, J.M., 2020. Characteristics of and Important Lessons From the Coronavirus Disease 2019 (COVID-19) Outbreak in China: Summary of a Report of 72314 Cases From the Chinese Center for Disease Control and Prevention. JAMA 323, 1239-1242. https://doi.org/10.1001/jama.2020.2648 
